\title{
Pengembangan Maqasid Al-Syari’ah Perspektif Thahir Ibnu 'Asyur
}

\author{
Sholikah \\ Sekolah Tinggi Ilmu Tarbiyah Makhdum Ibrahim Tuban Jawa Timur \\ Email: sholikah@stitmatuban.ac.id
}

\begin{abstract}
The essence of Islamic law is to attract the good (maslahat) of humans and reject the danger from it. Therefore, in addition to carrying out the shariah, humans are required to understand the aims and objectives of the shari'ah set. Departing from the above statement, this study will examine the efforts of Thahiribnu 'Asyur in developing concepts related to the science of maqasid al-shari'ah. The data of this research is library. The data collection method uses the documentation method, which is: collecting, then analyzing the data collected. After the data has been collected, data analysis is carried out by means of data reduction, presentation of data in narrative form, and drawing conclusions. This study concludes that the maqasid al-shari'ah, as stated by Thahir ibnu 'Asyur, is the spirit of all human actions relating to the laws established by Islamic shari'ah, especially in dealing with a number of problems in this millemnial era. In addition, said Thahir ibnu 'Asyur, the main reason for the decline of figh is the neglect of scholars towards the study of maqasid which results in the distortion of shari'ah values themselves. The opinion of Thahir ibnu 'Asyur above is supported by 'Allal al-Fasi, one of the experts in contemporary maqasid al-shari'ah, who asserted that the main condition for success in dialoguing fiqh with contemporary reality is the rise or failure of scholars' responses to the study of maqasid. This is where the role of maqasid al-shari'ah as the spirit of each figh law finds its momentum. Its elastic characteristics, across space and time, are expected to be able to dialogue with problems that continue to emerge. These characteristics are able to adapt to every civilization that runs and play a role in arousing Islamic civilization that is lagging behind other civilizations.
\end{abstract}

Keywords: maqasidal-shari'ah, maslahah, development.

\begin{abstract}
Abstrak
Inti syariat Islam adalah menarik kebaikan (maslahat) manusia dan menolak bahaya darinya. Karena itu, selain menjalankan syariat, manusia dituntut memahami maksud dan tujuan syari'at yang ditetapkan. Berangkat dari pernyataan di atas, penelitian ini akan mengkaji usaha Thahir ibnu'Asyur dalam mengembangkan konsep-konsep yang terkait dengan ilmu maqasid al-syariah. Data penelitian ini bersifat kepustakaan.
\end{abstract}


Metode pengumpulan datanya menggunakan metode dokumentasi, yaitu: mengumpulkan, kemudian menelaah data yang dikumpulkan tersebut. Setelah data terkumpul kemudian dilakukan analisis data dengan cara reduksi data, penyajian data dalam bentuk naratif, dan menarik kesimpulan. Penelitian ini menyimpulkan bahwa maqasid al-syari'ah, sebagaimana dinyatakan oleh Thahir ibnu'Asyur, merupakan ruh dari semua tindakan manusia yang berhubungan dengan hukum-hukum yang tetapkan oleh syariat Islam, terutama dalam menghadapi sejumlah permasalahan di era millenial ini. Di samping itu, kata Thahir ibnu'Asyur, sebab utama kemunduran fiqh adalah pengabaian para sarjana terhadap studi maqasid yang berakibat pada distorsi nilai-nilai syariat itu sendiri. Pendapat Thahir ibnu'Asyur di atas di dukung oleh 'Allal al-Fasi, salah satu pakar maqasid al-syari'ah kontemporer, yang menegaskan bahwa bahwa syarat utama keberhasilan mendialogkan fiqh dengan realitas kontemporer adalah marak atau tidaknya sambutan para cendekiawan terhadap studi maqasid. Di sinilah peran maqasid al-syariah sebagai ruh pada setiap hukum fiqh menemukan momentumnya. Karakteristiknya yang elastis, lintas ruang dan waktu, diharapkan mampu berdialektika dengan permasalahan yang terus bermunculan. Karakteristik tersebut mampu beradaptasi terhadap setiap peradaban yang berjalan dan berperan membangkitkan peradaban Islam yang tertinggal dengan peradaban lain.

KataKunci: maqasid al-syari'ah, maslahah, pengembangan.

\section{Pendahuluan}

Perkembangan pemikiran keIslaman dalam sejarahnya telah menunjukkan adanya varian-varian yang khas sesuai dengan semangat zamannya (AshShiddieqiy, 1998). Varian-varian itu berupa metode, visi, dan kerangka berpikir yang berbeda-beda antara satu pemikiran dengan pemikiran lainnya. Ajaran dan semangat Islam bersifat universal, rasional, dan necessary (suatu keniscayaan dan keharusan yang fitri). Akan tetapi akibat adanya respon historis manusia terhadap tantangan zaman yang berbeda-beda, maka hal tersebut menimbulkan corak dan pemahaman yang berbeda-beda pula (Abdullah, 1995).

Fiqh klasik, sebagai sebuah produk hasil penalaran dan ijtihad para ulama dimasa silam, kerap disalah artikan dan didudukkan sebagai entitas yang bersifat absolut. Kedudukan fiqh, sebagai sebuah penafsiran agama yang relatif, seringkali disamakan dengan agama itu sendiri, yang mutlak, bebas dari kesalahan. Implikasinya, setiap problem yang muncul di realitas kekinian, harus selalu merujuk pada kekuatan magis fiqh klasik dalam mencarikan jalan keluar. Akibatnya, semua fenomena yang terjadi di era kontemporer harus selalu patuh pada otoritas tunggal masa silam. Inilah penyebab produk fiqh yang dihasilkan menjadi mandul dan terkesan mengawang di atas cakrawala peradaban masa silam. 
Inilah penyebab kegagalan fiqh klasik dalam berdinamika dan berdialog dengan problem kekinian.

Pemahaman yang menyeluruh terhadap sejarah fiqh klasik akan melahirkan kesadaran betapa pentingnya mengedepankan fiqh maqasid ketimbang fiqh klasik yang selalu menempatkan teks di atas segalanya. Berangkat dari kenyataan tersebut, dan dengan mempertimbangkan bahwa spektrum realitas yang terus bertambah dan semakin menemukan intensitas pemahamannya, maka menempatkan maqasid al-syari'ah pada posisi central adalah sebuah keharusan demi terwujudnya eksistensi fiqh yang humanis, elastis dan egaliter. Belajar dari kegagalan fiqh klasik dalam merespon problematika era globalisasi sekarang ini, rekonstruksi dan reformasi rancang bangun fiqh yang berbasis pada kerangka kerja maqasid alsyari'ah sangat dibutuhkan untuk kemajuan umat Islam dalam mewujudkan kemaslahatan hamba.

Maqasid al-syari'ah, merupakan ruh, spirit, dan hakikat dari perintah dan larangan Islam. Penggunaannya sebagai spirit dalam penetapan hukum, telah dipraktekkan sejak masa hidup Rasulullah SAW, era sahabat, dan periode tabi'in. Sekalipun demikian, eksistensinya sebagai sebuah objek kajian ilmiah maupun sebagai sebuah aspek pertimbangan perumusan hukum, baru dimulai sekitar akhir abad III H. Adalah al-Hakim al-Tirmidzi, yang dianggap sebagai orang yang pertama menggunakan istilah "maqasid" dan menjadikannya sebagai sebuah objek kajian ilmiah dalam karyanya yang berjudul: al-Shalat wa Maqasiduha (Raisuni, 1995).

Pada tahap selanjutnya, perkembangan kajian mengenai maqasid al-syari'ah mengalami perkembangan cukup signifikan. Eksistensi maqasid al-syari'ah bukan hanya sebatas objek kajian ilmiah maupun spirit dalam hukum, tapi lebih jauh telah menjadi sebuah pendekatan dalam perumusan hukum itu sendiri. Implikasinya adalah perlu adanya standarisasi penggalian maqasid al-syariah dan penggunaannya. Hal ini penting, agar tidak dioperasionalkan secara liar dan out of control, sehingga tidak melahirkan produk ijtihad dan kebijakan hukum yang spekulatif dan serampangan.

Atas dasar pertimbangan ini, para ulama' secara sadar merumuskan aturanaturan khusus sebagai bentuk penertiban dalam upaya mendeteksi keberadaan maqasid al-syari'ah dalam kandungan setiap aturan syariat, sekaligus 
menetapkannya dalam status layak atau tidaknya untuk digunakan sebagai dasar pertimbangan perumusan dan istinbath hukum.

Di antara ulama komtemporer yang menawarkan konsep baru dalam berijtihad adalah Muhammad Thâhir ibnu 'Asyur, beliau merupakan salah seorang intelektual muslim kelahiran Tunisia yang sangat disegani dan dihormati. Thahir ibnu 'Asyur dikenal sebagai seorang ulama progresif dalam bidang hukum Islam, terutama yang terkait dengan ilmu maqasid al-syari'ah. Berkat pengembangannya terhadap ilmu tersebut, ia dianggap sebagai ulama' penerus ide Imam al-Syathibi yang dikenal sebagai bapak maqasid al-syari'ah (Mawardi, 2012).

Thahir Ibnu 'Asyur memawarkan gagasan tentang maqasid al-syari'ah sebagai sebuah acuan untuk ber-istinbath dalam hukum Islam. Menurutnya para ulama sangat membutuhkan kerangka pemikiran maqasid dalam konsep ijtihad dan penentuan hukum syariat. Dalam bukunya Maqasid al-Syari'ah alIslamiyyah dijelaskan tentang legalitas hukum maqasid dan urgensi penerapannya dalam merumuskan rancang bangun suatu hukum.

\section{Biografi Thahir Ibnu 'Asyur}

Nama lengkapnya adalah Muhammad Thahir ibnu Muhammad ibnu Muhammad Thahir ibnu 'Asyur. Beliau terlahir dari lingkungan keluarga istimewa, atau lebih tepatnya keluarga para ulama', seperti: Syeikh Ahmad ibnu 'Asyur, Muhammad ibnu 'Asyur, Muhammad Thahir ibnu 'Asyur al-Jad, dan kemudian Muhammad Fadhil ibnu 'Asyur. Beliau dilahirkan pada tahun 1879 M. di pinggiran kota yang bernama La Marsa, Tunisia (Al-Hasanî, 1995; Al-Misawî, 2001).

Thair ibnu 'Asyur memulai pendidikannya di usia enam tahun dengan belajar al-Qur'an dan menghafalkannya di bawah asuhan Syeikh Muhammad al-Khiyari. Kemudian dilanjutkan dengan mempelajari matan al-ajjurumiah dalam bidang nahwu dan kitab-kitab fiqh mazhab Maliki. Selanjutnya, pada tahun 1893 M. belajar di perguruan tinggi Zaituna, institusi pendidikan tinggi Islam tertua di wilayah Maghribi yang sudah eksis sejak abad $8 \mathrm{M}$. Di sana ia belajar ulum alQur'an, hadits, fiqh, ushul, sejarah, bahasa dan lain sebagainya, serta mendalami bahasa Perancis, bahasa resmi yang digunakan pemerintah kolonial Perancis di Tunisia ketika itu. Setelah selesai dari Zaituna, dengan mendapat ijazah tathwi', ia meneruskan belajarnya pada Menteri Besar Tunis, Syeikh Aziz Benasyur, Syaikh al- 
Islam Mahmud Benhowjah, salah satu pembesar madzhab Hanafi di Tunis, Syeikh Salim Benhajib seorang ulama besar mazhab Maliki, dan Syeikh 'Umar Ahmad, Imam besar mazhab Maliki. Keempat guru tersebut yang paling banyak memberikan pengaruh penting dalam perkembangan intelektual Thahir ibnu 'Asyur.

Karir akademis Thahir ibnu 'Asyur dimulai dengan menjadi tenaga pengajar di almamaternya, Zaituna, pasca mendapatkan ijazah tathwi' pada tahun $1899 \mathrm{M}$, dilanjutkan dengan keberhasilannya lulus menjadi ulama' tabaqat al-tsaniah pada tahun 1903 M, menjadi dosen di Madrasah al-Shadiqia pada 1904 M, naik pangkat sebagai ulama' thabaqat al-ula pada tahun $1905 \mathrm{M}$, menjadi anggota majelis reformasi, anggota pendidikan dan majelis auqaf, menjadi Hakim Agung mazhab Maliki tahun 1923 M, kemudian dilanjutkan dengan menjabat sebagai mufti besar wilayah Tunisia setahun sesudahnya.

Kehidupan beliau secara umum terbagi dalam dua fase besar yang memiliki pengaruh terhadap perkembangan pemikirannya.Pertama, era penjajahan kolonial Perancis atas negara-negara maghrib 'arabi (Maroko, Aljazair, Tunisia) dalam rentang waktu yang di mulai pada tahun 1881 M.-1956 M. Kedua, era kemerdekaan Tunisia pada tahun 1956 M. - 1973 M(Al-Hasanî, 1995).

Fase pertama kehidupannya diiringi oleh berbagai peristiwa besar di Dunia Islam, seperti melemahnya emperium kekhalifahan Turki Utsmani. Kondisi tersebut dimanfaatkan oleh negara-negara emperialis Eropa untuk melakukan penjajahan terhadap negara-negara Islam di Timur Tengah, termasuk Tunisia tempat lahir dan perkembangan kehidupan beliau.

Penjajahan yang terjadi menuntut rakyat Tunisia untuk berjuang bangkit dari keterpurukan. Pada proses menuju kemerdekaannya, ada beberapa faktor yang melatarbelakanginya.Pertama, pengaruh pejuang reformasi Islam dari Mesir, Muhammad Abduh. Gagasan mengenai "wacana pembaharuan Islam" yang digagas dan disebarkan berkala melalui media cetak "Urwatul Wutsqa" sangat mempengaruhi pola pikir para cendekiawan Tunisia, termasuk Thahir ibnu 'Asyur yang kala itu merupakan salah satu dari mereka. Terlebih pasca kunjungan kedua Abduh ke Tunisia (1903 M.) yang semakin melecutkan semangat para cendekiawan Tunisia dalam pemikiran. Wajar jika kemudian Thahir ibnu 'Asyur disebut terpengaruh oleh Abduh disamping al-Afghani, Rasyid Ridha, dan lainnya. 
Kedua, pengaruh tokoh internal Tunisia yaitu Khairudin al-Tunisi yang berusaha menggeliatkan gairah keilmuan melalui revitalisasi kinerja pers dan pemikiran, termasuk pencetakan dan penyebaran besar-besaran kitab klasik, diantaranya pencetakan pertamaal-Muwâfaqât (Al-Hasanî, 1995). Dengan karyanya yang bejudul: Aqwâm al-Masâlik fì Márifati al-Ahwâl al-Mamâlik,"ia berusaha menggugah umat Islam untuk mencontoh model kemajuan negaranegara Eropa dalam beberapa aspek. Ketiga, tergeraknya para tokoh berpengaruh saat itu untuk merekonstruksi ulang sistem pendidikan. Di sinilah perhatian maqasid pertama Thahir ibnu 'Asyur muncul melalui kitabnya, Alaisa al-Shubhu bi Qarîb, yang mengkritik sistem pendidikan melalui kacamata maqasid.

Fase kedua, kehidupan pasca kemerdekaan. Pada fase ini beliau mencurahkan segenap tenaga dan pikirannya dalam dunia pendidikan. Selain menjabat sebagai staf pengajar resmi di universitas, banyak prestasi yang dicapainya antara lain menjadi Hakim Agung mazhab Maliki dan sebagai Mufti Agung Tunisia pada tahun 1926 M. Kecermelangan karirnya juga membawanya turut aktif dalam dunia Internasional seperti sebagai anggota Majma' Lughah 'Arabiyah (Pusat Studi Bahasa Arab) di Kairo Mesir pada tahun 1940 M, sebagai anggota utusan Majma ‘ al- 'Ilmi al- 'Arabi Damaskus pada tahun 1955 M (Khalid, 1995).

Sepanjang pengembaraan intelektualnya, Thahir ibnu 'Asyur banyak melahirkan karya-karya ilmiah, baik berupa syarah (penjelasan) atas karya cendekiawan lain, tahqiq (komentar), kumpulan syair, dan buku-buku ilmiah. Karya beliau sebagai pemikir profilik diantaranya, yaitu: Tahrîr Ma'na al-Sadîd wa Tanwîr al-'Aql al-Jadîd min Tafsîr al-Kitâb al-Majîd; Maqâsid al-Syarî́ah alIslâmiyah; Ushûl Nidzam al-Ijtimâ'fî al-Islam; Alaisa al-Shubhu bi Qarîb; Naqd 'Ilmi likitâb al-Islâm wa Ushûl al-Hukmi, dan masih banyak lagi karya-karyanya yang tersebar dan belum sempat terbukukan.

Dari sejumlah karya Thahir ibnu 'Asyûr, kitab Maqâsid al-Syarî'ah al-Islâmîyah merupakan salah satu master piece-nya. Metode penulisan kitab tersebut terbagi dalam tiga kerangka besar, antara lain: pertama, pembahasan mengenai penetapan tujuan syarîat. Kebutuhan seorang faqîh untuk mengetahui maqâsid al-syarîtah, metode-metode penetapan dan tingkatan-tingkatannya; kedua, mengulas tentang maqâsid al-syarîtah umum; dan ketiga, membahas maqâsid al-syarî́ah khusus dengan segala macam horizonnya dalam ranah fiqh mu'âmalât ('Asyur, 1984). 
Kitab ini sebagai basis teoretis maqâsid al-syharî́ah dari Thahir ibnu 'Asyûr, sedangkan aplikasi maqâsid al-syarî́ah pada hukum-hukum tertentu, baik ibadah atau mu'âmalat, lebih banyak ia tuangkan dalam karya-karyanya yang lain, semisal tafsir Tahrîr Ma'nâ al-Sadîd wa Tanwîr al'Aql al-Jadîd min Tafsîr al-Kitâb al-Majî̀ atau yang terkenal dengan sebutan tafsir al-Tahrîr wa al-Tanwîr-nya dan lain sebagainya.

\section{Historisitas Perkembangan Maqasid al-Syari'ah}

Islam adalah agama terakhir yang diturunkan Allah di muka bumi ini. Sebagai agama penyempurna agama-agama sebelumnya, Islam mengandung tujuan luhur dan maksud mulia yang mengarah pada manusia itu sendiri sebagai mukallaf (obyek yang dikenai kewajiban syariat). Ia mengandaikan adanya seperangkat hikmah yang mengiringi turunnya syarian. Apa yang disyari'atkan Allah SWT tidak terlepas dari hikmah (QS, Al-Mu'minun: 115; QS, al-Baqarah: 185; QS, alMaidah: 6; QS, al-Hajj: 78; QS, al-Nisa: 28; QS, al-'Ankabut: 45).

Dari sini dapat dikatakan bahwa munculnya maqasid al-syariah telah ada bersamaan dengan wahyu pertama yang diterima oleh Nabi Saw. Keberadaan maqasid al-syari'ah ini terus berjalan beriringan dengan wahyu-wahyu yang turun pada periode setelahnya. Maqasid al-syari'ah dapat ditemukan pada fatwa, perintah, maupun produk hukum yang bersumber dari al-Qur'an dan sunnah Nabi SAW. Sebagai contoh, syara' memerintahkan manusia untuk tidak mencampuri istrinya dalam keadaan haidh demi menjaga kesehatan karena secara medis, darah haidh banyak mengandung kuman yang berbahaya. Hikmah disyariatkannya nikah sebagai jalan untuk merealisasikan ketentraman manusia dan melestarikan keturunan, dan tujuan diperintahkannya berjihad $f i$ sabilillah untuk menjaga keamanan komunal masyarakat dan mempertahankan diri terhadap intervensi asing.

Nabi Muhammad SAW, sebagai manifestasi tunggal wakil Tuhan dimuka bumi, secara bijak tidak pernah memberikan perintah atau anjuran kecuali dengan terlebih dahulu mempertimbangkan psikologi umat dan kondisi sosio historis mereka. Jejak kebijakan Nabi SAW ini dapat kita temukan pada sabda-Nya, seperti "Sesungguhnya agama ini mudah," "Allah menghendaki kemudahan bagimu," "Kalaulah tidak mempersulit umatku, niscaya akan Aku perintahkan mereka untuk bersiwak sebelum sholat," dan masih banyak lagi sabda-sabda-Nya yang 
menunjukkan adanya pertimbangan kemaslahatan umum dalam menetapkan sebuah hukum. Kebijakan Nabi SAW seperti ini, dilanjutkan oleh para sahabat dan generasi-generasi setelahnya. Karakteristik unik syariat Islam dalam merumuskan rancang bangun hukum dengan disertai pertimbangan kemaslahatan umum, gradualitas turunnya wahyu (tadarruj nuzul), konsep mencari kemaslahatan dan mencegah kemudharatan (jalb al-masalih wa daf u al-madharrat) perlahan mulai dikembangakan oleh para ulama' menjadi suatu konsepsi utuh yang pelan-pelan menjadi sebuah teori maqasid al-syari'ah .

Perjalanan maqasid al-syari'ah menjadi suatu disiplin ilmu secara mandiri tidak terjadi seketika. Tercatat mulai generasi sahabat, perhatian akan maksud dan tujuan dari syariat mulai dikembangkan sesuai dengan perkembangan zaman ketika mereka hidup. Karena syariat adalah sesuatu yang hidup ( $k a^{\prime} i n$ hayy) yang bisa menyesuaikan diri sesuai dengan peradaban yang di hadapi. Tuntutan untuk mengembangkan syariat tanpa melepaskan diri dari tujuan utama 'memaksa' mereka untuk melakukan berbagai inovasi kreatif dalam merumuskan rancang bangun suatu produk hukum. Pengangkatan Abu Bakar sebagai khalifah pertama untuk menjaga persatuan dan keutuhan umat, pengumpulan al-Qur'an dalam satu mushaf di masa Usman, ditiadakannya hukuman potong tangan oleh Umar dimasa paceklik, adalah beberapa contoh bentuk terobosan jitu para sahabat dalam mengembangkan syariat, dengan mengembangkannya sesuai masa dimana mereka hidup, dengan tanpa mengabaikan hikmah luhur turunnya syariat itu sendiri.

Sejalan dengan sahabat, tabi' in juga memasukkan unsur maqasid al-syari'ah sebagai salah satu pertimbangan keputusan hukum. Di masa tabi' in dikenal adanya dua madrasah yang berkembang pesat, yaitu: Hijaz dengan madrasah atsariah-nya, dan madrasah Iraq dengan madzhab ra'yu-nya. Pada madrasah Hijaz, meskipun kecenderungan tekstualis lebih mendominasi, akan tetapi aplikasi penggunaan maqasid al-syari'ah tidak dapat diabaikan begitu saja. Pengaruh besar ijtihad para sahabat seperti: Umar ibnu al-Khattab, Abu Hurairah, dan Siti 'A'isyah yang melandaskan pandangannya kepada asas masalih al-mursalah, jalb al-masalih, dar' al-mafasid, ikut terserap dan turut mewarnai alur pikir para mujtahid generasi sesudahnya (Raisuni, 2003). Sementara untuk madrasah Iraq, meskipun terkenal dengan mazhab ra'yu-nya, tidak berarti mengesampingkan teks-teks keagamaan begitu saja. Penggunaan ra'yu tetap harus berlandaskan pada atsar sahih dan 
pendapat para salaf al-salih serta mengutamakan kemaslahatan dan urf hasanah (tradisi yang baik). Sementara madrasah Hijaz banyak menggunakan ijtihad Umar dan Siti 'A'isyah, maka madrasah Iraq lebih banyak memakai ijtihad Ali ibnu Abi Thalib, Abdullah ibnu Mas'ud, dan Ibrahim an-Nakha'i yang lebih mengedepankan akal dan kemaslahatan bersama ketika menemukan masalah yang tidak disinggung oleh teks (Al-Khadimy, 1998).

Setelah era tabi'in, studi maqasid al-syariah terus mengemuka. Perlahan namun pasti, satu persatu ulama dan cendekiawan mulai mengupas lebih dalam beragam sisi lain dari konsep ini. Setelah pada periode sebelumnya istilah maqasid al-syari'ah hanya dapat dikenali secara parsial dari kecenderungan-kecenderungan rumusan konsep penggalian hukum, maka pada fase ini para ulama' mulai memberikan ruang khusus kajian ini. Tercatat al-Hakim al-Tirmidzi (abad $3 \mathrm{H}$ ) adalah orang yang pertama kali menggunakan kata maqasid dalam kitabnya alSholah wa maqasiduha, yang menguraikan tentang tujuan dan hikmah dari ibadah sholat. Kemudian diikuti oleh karya-karya lainnya yang masih membahas seputar hikmah-hikmah tertentu dari bermacam-macam ibadah, seperti al-Hajj wa Asraruhu, al-'Illah, 'Ilal al-Syari'ah, 'Ilal al-Ubudiyyah dan al-Furuq. Setelah alTirmuizi kemudian datang Abu Mansur al-Maturidi (w. 333 H) dengan karyanya Ma'khad al-Syara'. Kemudian disusul Abu Bakar al-Qaffal al-Syasyi (w. 365 H.) dengan kitab Ushul al-Fiqh dan Mahasin al-Syari'ah, Abu Bakar al-Abhari (w. 375 H.) dan al-Baqilany (w. $403 \mathrm{H}$ ) masing-masing dengan kitab Mas'alah al-Jawab wa al-Dalail wa al-'Ilah dan al-Taqrib wa al-Irsyad fi Tartib Thuruq al-Ijtihad. Pasca alBaqillany muncullah Imam Haramain al-Juwaini (w. 478 H.) dengan kitab alBurhan, al-Waraqaat, al-Ghiyatsi, Mughitsul Khalq, al-Ghazali (w. 505 H.) dengan kitab di bidang fiqh dan ushul fiqh, seperti: al-Mustashfa, al-Mankhul, al-Wajiz, Ihya Ulumiddin dan Syifa al-Ghalil, al-Razy (w. 606 H.) dengan kitab Mafatih al-Ghaib, al-Ayat al-Bayyinat, al-Mahshul dan Asas al-Taqdis, Saifuddin al-Amidi (w. 631 H.) dengan kitab al-Ahkam, dan Ghayatul Maram, Ibn Hajib (w. $646 \mathrm{H}$ ) dengan kitab Nafais al-Ushul, Syarh al-Mahsul, al-Furuq, al-Ihkam fi Tamyiz al-Fatawa 'an alAhkam wa Tasharruf al-Qadhi wal Imam, al-Baidhawi (w. 685 H.), al-Asnawi (w. 776 H), Ibn Subuki (w. 771 H.), 'Izzuddin Abdussalam (w. 660 H.) dengan Qawaid al-Ahkam fi Masalih al-Anam, al-Qarafi dengan kitab al-Faruq-nya, al-Thufi (w.716 H.), Ibn Taimiyyah (w. 768 H.) dan Ibn Qayyim (w.751 H.).

\section{Thahir ibnu 'Asyur dan Pengembangan Studi Maqasid al-Syari'ah.}


Pasca wafatnya al-Syatibi pengembangan maqasid mengalami kemandegan. Wacana maqasid yang pertama kali terkodifikasikan dengan rapi dan sistematis oleh Imam al-Syatibi mendadak hilang tak berbekas. Barangkali salah satu faktor redupnya sinar diskursus maqasid ini disebabkan oleh jatuhnya kekuasaan daulah Islam di Andalusia ke tangan penguasa Kristen Spanyol. Saat itu terjadi pengusiran besar-besaran umat Islam (mahkamah taftisy) dari tanah Andalusia, peradaban Islam lenyap berserta karya-karya agung yang sempat terbukukan, termasuk bukubuku karya al-Syatibi.

Pada paruh pertama abad 20, Thahir ibnu 'Asyur tampil sebagai bapak reformasi studi maqasid, yang menawarkan pendekatan baru dalam mempelajari maqasid al-syariah sesuai dengan realitas kekinian dan konteks modern. Upaya reformasi ini, tertuang dalam karya monumentalnya, Maqasid al-Syari'ah alIslamiah yang terbit pertama kali di Tunisia, tahun 1946 M. Dalam buku ini, ia mengarahkan studinya pada penyingkapan rahasia dan hikmah diturunkannya syariat, yaitu: sebagai pemberi solusi ketika muncul ikhtilaf diantara para ulama', baik karena perbedaan masa hidup, kondisi sosial masyarakat, atau perbedaan kadar kemampuan dalam perumusan suatu hukum ('Âsyûr, 2001).

Tawaran Thahir ibnu 'Asyur ini, dapat menjadi alat untuk meminimalisir adanya perbedaan diantara kaum muslimin, dan untuk mengurangi kecenderungan fanatik sempit pengikut mazhab tertentu dan disintegrasi umat. Pada bagian pertama buku tersebut, Thahir ibnu 'Asyur membagi dalam 3 kategori besar. Pertama adalah legalitas hukum maqasid dan urgensi penerapannya dalam merumuskan rancang bangun suatu hukum. Mengenai legalitas maqasid, seperti disebutkan dimuka, bahwa Allah sebagai sang pemilik syariat mustahil untuk menurunkan syariat kepada manusia tanpa diiringi dengan tujuan dan hikmah mulia. Hal ini nampak jelas apabila kita telusuri sejumlah ayat al-Quran yang mengisyaratkan akan hal tersebut, seperti tersebut dalam QS. al-Dukhan ayat 3839, al-Mu'minun ayant 115, al-Hadid ayat 25, Ali Imran ayat 19, al-Nisa ayat 171, al-Syura ayat 13, al-Maidah ayat 44-48, dan al-Baqarah ayat 179 .

Seorang mujtahid, sebelum merumuskan suatu teori maqasid dituntut untuk menguasai beberapa hal berikut, yaitu: mengetahui secara paripurna maksud dari sebuah teks dan latar belakang turunya teks tersebut ( $a s b a b$ al-nuzul), melakukan observasi metodologis pada teks-teks yang berlawanan dhahirnya, melakukan analisa atas teks yang ambigu dengan menganalogikannya pada teks lain yang 
menunjukkan hukum secara jelas, serta melakukan kompromi metodologis dengan meletakkan maqasid al-syari'ah sejajar dengan teks agama untuk kemudian didialogkan dengan realitas kekinian, demi terciptanya konsep fiqh yang hidup, humanis, dan mengakomodir kemaslahatan umum.

Secara esensi, ada sejumlah perbedaan di kalangan ulama' terkait dengan makna lahir teks. Karena suatu kata, tidaklah diletakkan kecuali untuk membebaskan makna yang terkandung di dalamnya. Setiap teks yang hadir, tidaklah selalu menunjukkan pada satu makna tunggal yang baku. Ia mengandaikan adanya pancaran makna dari tiap sisi yang berbeda. Dari sini perbedaan pemahaman para ulama' adalah hal yang lumrah mengingat masingmasing dari mereka mempunyai titik bidik yang beragam atas teks. Dalam kerangka membangun kesepahaman antar ulama' inilah keberadaan maqasid menjadi sangat diperlukan. Ia bisa menjadi semacam entitas pemersatu dari berbagai kecenderungan, dimana semua aliran dapat berdamai dan bertemu dalam satu muara yang sama, yaitu kemaslahatan.

Thahir ibnu 'Asyur, selanjutnya, memberikan analisa atas tindakan Rasulullah, sebagai instrumen pelaksana syariat Tuhan, dimana dalam pandangannya mengandung 12 dimensi metodis ('Âsyûr, 2001), yaitu: tasyri', fatwa, qadha', imarah, huda wa al-irsyad, suluh, isyarah ala al-mustasyir, al-nasihah, takmil al-nufus, ta'lim al-haqaiq al-'aliya, ta'dib, al-tajarrud 'an al-irsyad. Dari kesemua dimensi ini, ia hendak memberikan suatu konklusi bahwa sejatinya muara yang hendak dituju oleh syariat adalah satu, sedangkan jalan yang ditempuh adalah banyak dan beragam. Oleh karena itu, tidaklah bijaksana apabila kita terus memperdebatkan wasail tanpa memandang prinsip-prinsip utama dari dibangunnya wasail tersebut, yaitu maslahat.

Thahir ibnu 'Asyur menggunakan teorinya dengan basis epistemologi qath'iyyat al-maqasid al-syari'ah. Dalam masalah ini ulama' terbagi dua kubu yang berlawanan. Sebagian berpandangan bahwa maqasid bersifat $d z a n n i$, sedangkan di lain pihak maqasid bersifat qath'i (Al-Hasanî, 1995).

Sebagai pihak yang berada di kubu kedua, Thahir ibnu 'Asyur berpandangan bahwa syari'ah bukanlah seperangkat hukum yang nir-hikmah. Hikmah dapat diamati melalui kandungan ayat-ayat al-Qur'an. Hikmah ini termuat dalam janji Allah untuk menjaga syariat-Nya dan menyempurnakan agama-Nya di muka bumi (Al-Hasanî, 1995). Karena itu, ia sepakat dengan pendapat al-Syatibi yang 
mengatakan bahwa ilmu ushul fiqh, sebagaimana ilmu maqasid, berlandaskan pada basis epistemologi dan struktur pengetahuan yang bersifat qath'i yang ditopang oleh dua pendekatan, yaitu: aqli dan naqli. Pendekatan aqli dapat dilacak dengan melakukan observasi langsung pada ayat-ayat hukum atau perintah yang mengisyaratkan pada maslahat 'ammah. Sementara pendekatan naqli dapat diketahui dari banyaknya ayat yang menghendaki adanya penjagaan dan penyempurnaan Islam.

Selanjutnya, metode mengetahui maqasid al-shari'ah, menurut al-Syatibi, ada 3 kecenderungan metodologis. Pertama, kecenderungan yang diperankan oleh sekte Dhahiriyyah, dimana maqasid al-syari'ah hanya dapat diketahui apabila kita membiarkan dhahir teks berbicara apa adanya. Sementara golongan kedua, sekte Bathiniyah, menafikan adanya teks yang berbicara atas namanya sendiri, tetapi sebaliknya maksud teks adalah apa yang berada pada makna batin dari suatu teks. Golongan ketiga, Jumhur Ulama', berusaha menyelaraskan antara perspektif dhahir dengan batin dari suatu teks. Bagi golongan ini, yang paling penting adalah bagaimana kita secara intens mengambil dhahir teks, tanpa mengabaikan batin, begitu pula sebaliknya, agar kita bisa mendapati teks berjalan beriringan dengan makna di dalamnya.

Berbeda dengan al-Syatibi, Thahir ibnu 'Asyur mencoba menawarkan perspektif baru tentang metode menemukan maqasid al-shari'ah. Ia membaginya dalam tiga bagian. Pertama, dengan menganalisa maqasid al-shariah melalui perintah (amr) dan larangan (nahi). Kedua, dengan mengetahui ratio-legis ('illah) dari suatu hukum, seperti perintah nikah untuk melestarikan keturunan, jual beli untuk menarik manfaat dari barang yang dibeli, dan sebagainya. Ketiga, berangkat dari sebuah pandangan bahwa maqasid al-syari'ah selalu mengandung dua dimensi, yaitu dimensi ashliyah dan taba'iyyah, yang terkadang terlihat jelas pada dhahir teks dan terkadang juga hanya berupa isyarat. Dalam konteks ini, yang perlu diperhatikan adalah bahwa walaupun maqasid al-syari'ah tidak tersebut pada dhahir teks, bukan berarti ia tidak ada. Keberadaannya dapat dirasakan setelah adanya perenungan terhadap teks untuk mendapatkan spirit dasarnya. Alasan inilah yang memastikan Thahir ibnu 'Asyur untuk menolak anggapan yang

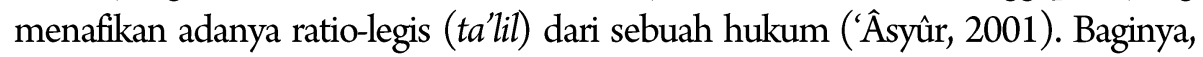
keseluruhan perintah syara' pasti mengandaikan adanya 'illah (sebab hukum) dan tujuan keberadaannya. 
Selanjutnya pada bagian kedua buku tersebut, Thahir ibnu 'Asyur membahas maqasid al-syari'ah al-ammah. Dalam pembahasan ini, ia ingin menegaskan posisi penting universalitas dalam seluk beluk syariah. Menurutnya, universalitas merupakan salah satu karakter unik Islam. Dengan universalitas, Islam dapat mengambil tempat dan menyesuaikan diri dengan perkembangan zaman. Eksistensi universalitas tidakah terpisah maqasid. Ia berjalan beriringan dan bersama-sama saling menegaskan peran pentingnya masing-masing dalam membumikan Islam. Dengan universalitas, syari'ah dapat dijalankan dalam berbagai peradaban yang berbeda dengan nilai-nilai budaya Arab, tempat Islam pertama kali diturunkan. Sementara dengan maqasid, ia dapat merumuskan suatu tujuan bersama walaupun berbeda metode ijtihad. Beragam metode yang ditempuh oleh para mujtahid dalam merumuskan rancang bangun hukum Islam dapat ditengahi oleh maqasid al-syari'ah.

Thahir ibnu 'Asyur memberikan sejumlah persyaratan untuk menggali spirit dasar dari sebuah teks. Syarat-syarat ini ia berikan demi membedakan keberadaan spirit hakiki dari sebuah teks dari spirit awhami atau khayali. Syarat pertama yang diajukan oleh Ibnu Asyur adalah al-tsubut, yang berarti tetap atau pasti. Hal ini berarti eksistensi spirit dasar dari sebuah teks itu bersifat pasti dan tidak mengadaada. Hal ini dapat dikenali dengan adanya dilalah qawiyah dari sebuah teks, dan teks-teks lain yang berkeyakinan senada akan adanya sebuah entitas yang dimaksud.

Kedua adalah al-dzuhur yang bermakna muncul atau jelas. Secara singkat ia dapat diartikan sebagai suatu dilalah yang memancar dari balik teks, dimana makna teks itu dapat teraba secara jelas pada benak para sarjana. Syarat ketiga adalah alindzibath yang mengandaikan adanya suatu batasan yang jelas dan mengarah pada tujuan yang dimaksud. Sedangkan syarat terakhir adalah al-ithirad yang berarti menegasikan adanya gesekan pemahaman yang dilatarbelakangi perbedaan letak geografis, tradisi budaya dan nilai-nilai zaman ('Âsyûr, 2001).

Realitas merupakan faktor penentu berhasil tidaknya suatu aktifitas ijtihad. Perbedaan realitas kehidupan sering memaksa para sarjana Islam, baik klasik maupun kontemporer untuk mengubah hasil ijtihadnya karena dirasa kurang mampu mengakomodir nilai-nilai syari’at ketika diaplikasikan pada peradaban yang berbeda. Ini bukan berarti menegasikan kesempurnaan ajaran Islam, malah 
sebaliknya itu bisa dimaknai dengan elastisitas Islam sebagai agama yang fleksibel dan adaptif terhadap beragam nilai-nilai budaya yang berbeda.

Parameter elastisitas Islam dapat dilihat dari kesesuaiannya dengan fitrah bawaan manusia terlepas darimana ia dilahirkan, dan pengaruh nilai-nilai adat yang berkembang pada peradabannya. Sembari menyitir beberapa teks yang mengisyaratkan hal itu (QS. al-Rum: 11,30, dan al-Syura: 13), Thahir ibnu 'Asyur menjelaskan bahwa yang dimaksud dengan fitrah manusia adalah "seperangkat aturan yang dilekatkan oleh Allah sejak awal mula penciptaan manusia, baik secara dhahir ataupun batin". Dhahir di sini bermakna segala hal yang bersifat jasadi dan inderawi seperti manusia berjalan dengan kedua kakinya, atau menggunakan matanya untuk aktifitas melihat. Sedangkan batin lebih bersifat aqli, yaitu manusia diciptakan dengan sejumlah kaedah-kaedah aplikatif dalam penggunaan akal.

Terlepas dari budaya yang berkembang dan menjadi tradisi, manusia pada dasarnya dapat secara aktif membedakan hal-hal yang baik atau buruk. Dan hal kedua inilah yang diyakini oleh Thahir ibnu 'Asyur, bahwa sifat Islam sebagai agama fitrah tak lain adalah fitrah aqli, dimana manusia, secara bawaan dapat mengikuti hal-hal yang ditawarkan oleh Islam, sepanjang hal itu masih berkesuaian dengan akal. Ini bukan berarti Islam selalu selaras dengan pluralitas berbagai budaya, sebagaimana disuarakan oleh beberapa kalangan, namun yang jadi titik tekan adalah Islam selalu membawa nafas yang sesuai dengan nilai budaya yang baik, dan budaya yang baik selalu selaras dengan kaedah-kaedah akal murni ('Âsyûr, 2001).

Melalui pijakan yang bernama fitrah ini, Thahir ibnu 'Asyur lantas berusaha mengembangkan teorinya. Ia menjelaskan bahwa asas fitrah adalah asas yang paling adil diterapkan kepada seluruh manusia, tanpa memandang ras, budaya, agama dan letak geografis. Oleh karena fitrah manusia berlaku syamil (menyeluruh) kepada seluruh manusia, maka syariah, sebagai entitas yang berkelindan dengan fitrah juga mengandaikan ke-umum-an (syumuliyyah) hukum Tuhan, baik bersifat zamani maupun makani. Umum zamani berarti tidak bersifat temporal sebatas masa tertentu, sementara umum makani berarti menembus sekat-sekat kesukuan, ras dan kawasan geografis tertentu ('Asyur, 2006).

Thahir ibnu 'Asyur melengkapi basis teorinya, merambah pada konsep egaliterianisme (al-musawah) yang merupakan sebuah kelanjutan metodologis dari kedua asas di atas, fitrah dan syumuliah. Menurutnya, egaliterianisme sejatinya 
telah terpatri sejak manusia ada di muka bumi. Apa yang datang dari syara' mesti mengandung makna persamaan. Dengan demikian syara' memandang asas almusawah bagi manusia, persis seperti persamaan mereka dalam hal penciptaan. Almusawah dalam syara' adalah al-ashl, yang tak berubah sampai ada dalil yang mencegahnya dan menunjukkan makna khususiyyat. Penghalang (awaridh mani'ah) ini terpatri dalam 4 hal; jibilliyyah (watak), syar'iyyah, ijtimaiyyah (sosial), dan siyasiyyah (politik).

Adapun contoh mani'ah jibilliyyah adalah seperti diferensiasi antara pria dan wanita dalam beberapa diskursus tertentu. Wacana ini, bukan berarti menjurus pada hal-hal yang sifatnya tidak sensitif gender, sebaliknya pola diferensiasi ini timbul karena perbedaan alamiah antara pria dan wanita, seperti perbedaan pembagian tugas mencari nafkah sebagai kewajiban suami dan melahirkan serta menyusui anak pada istri. Pola diferensiasi seperti ini tidak baku, ia bisa bersifat kondisional sesuai dengan situasi yang menuntut. Akan tetapi tesis ini diajukan oleh Thair ibnu 'Asyur merujuk pada kondisi normal yang biasa terjadi. Kemudian adalah mani'ah syar'iyyah yaitu penghalang yang datang dari syariah. Seperti dibolehkannya poligami bersyarat pada laki-laki, yang salah satu hikmahnya adalah menjaga garis keturunan, hal ini tidak bisa didapatkan pada sistem poliandri. Sedangkan mani'ah ijtmaiyyah adalah sesuatu penghalang yang didapatkan dari sitem sosial yang berlaku, seperti peran sosial para cerdik pandai yang tentu saja berbeda dengan masyarakat awam. Sementara yang terakhir adalah mani'ah siyasiyyah adalah penghalang yang berlaku akibat stabilitas politik yang berubah. Contoh konkrit dalam hal ini adalah perintah Nabi Saw saat Fath Makkah, "Barang siapa yang masuk rumah Abu Sufyan, maka ia aman (Al-Hasanî, 1995).

Ide-ide elegan Thahir ibnu 'Asyur tidak berhenti sampai di sini. Karena untuk mempermudah aplikasi dari ketiga prinsip di atas, ia mecoba untuk mempromosikan dua entitas mandiri, samahah (kemudahan) dan hurriyyah (kebebasan). Kedua entitas tersebut bergerak seiring seirama satu sama lain. Dengan samahah, Thahir ibnu 'Asyur ingin menegaskan bahwa agama itu mudah untuk dipahami. Ia tidak memerlukan beragam prosesi liturgi yang njelimet dan mbulet. Ia hanya menghendaki pola keberagamaan yang sederhana, tanpa terjebak pada arus penyederhanaan agama. Dalam perspektif mayoritas agamawan yang kemudian diamini juga oleh Ibnu 'Asyur, Islam selalu berjalan diantara dua kecenderungan ekstrim, tafrith dan ifrath. Bersikap tawassuth dan itidal bukan 
semata keharusan yang diperintahkan agama, melainkan juga sebentuk harmonisasi fitrah bawaan dengan tindakan aplikatif manusia di realitas nyata. Di sini Thahir ibnu 'Asyur menyatakan bahwa hikmah nyata dari samahah (QS, alNisa: 171; al-Baqarah: 185) dan sabda adalah ia bersesuaian dengan fitrah manusia, yang pada dasarnya selalu menghendaki kemudahan. Allah menurunkan syariat ini muabbadah dan 'ammah kepada seluruh manusia, sudah barang tentu ini mengandaikan adanya sebentuk kemudahan dan fleksibilitas agar dapat diterima secara terbuka oleh lintas generasi dan geografis ('Asyur, 2006).

Proses untuk mengaplikasikan semua konsep di atas, manusia harus diberikan perangkat hurriyyah (kebebasan). Secara esensi, kebebasan, dapat dimaknai sebagai suatu tindakan bebas yang dapat dipertanggungjawabkan baik secara moral (kepantasan di masayarakat), intelektual (logika manusia), dan spiritual (berdasarkan nilai agama). Kebebasan adalah keadaan dimana kita bisa melakukan segala sesuatu yang kita inginkan dan tidak terbelenggu lagi oleh aturan apapun (merdeka).

Lebih lanjut Thahir ibnu 'Asyur menegaskan kembali bahwa risalah yang dibawa Islam adalah sebentuk konsep teologi pembebasan. Ia datang untuk membebaskan manusia dari belenggu perbudakan, baik bersifat fisik atau non fisik. Ia datang pertama kali ketika hukum perbudakan merupakan suatu pranata sosial yang diterima publik secara luas, mulai kekasiaran Romawi kuno, kerajaan Persia, sampai peradaban Yunani. Sudah menjadi konsensus umum waktu itu bahwa perbudakan adalah suatu hal yang wajar dan bisa diterima. Sehingga tidak salah jika kemudian hal ini juga diadaptasi oleh Aristoteles, filosof kuno Yunani ketika mengemukakan tesisnya tentang keluarga ideal, yang menurutnya harus terdiri dari ayah, ibu, anak dan budak (Santhleir, 2008).

Dalam konteks di atas risalah Islam datang mengambil tempat untuk melepaskan manusia dari fenomena ketidakadilan dan menginjak harkat martabat manusia tersebut. Dengan karakternya yang berangsur-angsur dalam menetapkan suatu hukum (tadarruji), Islam perlahan mulai menghapuskan sistem yang sudah terlanjur menggurita tersebut. Ia mencoba meminimalisir munculnya kecenderungan baru perbudakan dan memberikan solusi kongkret untuk mengurangi praktek perbudakan yang sudah ada. Hal ini diwujudkan oleh Islam dengan melarang seseorang menjual dirinya atau orang tua yang menjual anaknya sendiri, melarang dijadikannya tawanan perang sebagai budak dan menggantinya 
dengan jasa mengajari kaum muslimin baca-tulis. Sementara untuk mengurangi praktek perbudakan yang sudah ada Islam menganjurkan pemilik budak untuk menggauli mereka dengan baik, menjadikan budak sebagai salah satu golongan yang berhak menerima zakat, dan menjadikan memerdekakan budak sabagai salah satu kafarat dari berbagai pelanggaran syariat, seperti; membunuh tanpa sengaja, berhubungan suami istri pada siang hari bulan Ramadhan, dzihar, dan sebagainya (QS, al-Baqarah; 177, al-Nur: 33, al-Balad: 11-13).

Sementara perbudakan yang bersifat non fisik meliputi adanya sebentuk pemaksaan otoritas tertentu yang hendak memonopoli suatu mazhab ideologi dengan meminggirkan pihak-pihak lain yang berseberangan, pengekangan kebebasan bersuara dan berserikat, serta pengebiran akan nilai-nilai demokrasi yang mana dimata Ibnu 'Asyur merupakan wujud perbudakan yang hendak dibebaskan oleh Islam. Perbuatan seseorang yang tidak dilandasi dengan kebebasan penuh sang empunya di mata Tuhan bernilai nol. Manusia sebagai makhluk yang merdeka bebas untuk menentukan ke arah mana dirinya akan bergerak, sepanjang kebebasan tersebut diiringi dengan sebentuk tanggung jawab penuh akan perbuatan yang dilakukannya.

Berdiri memusuhi kebebasan adalah sebuah kedhaliman, tegas Ibnu 'Asyur. Kemudian ia mencontohkan sebentuk kebebasan ideal yang terjadi di tiga kurun awal Islam. Ketika itu, masyarakat bebas memilih mazhab dan hasil penalaran ijtihad yang sesuai dengan keadaannya. Setiap sarjana yang mempunyai kapabilitas dalam proses afirmasi hukum (istinbath) berhak untuk merumuskan hasil ijtihadnya sendiri tanpa ada intervensi dari pihak asing. Tidak ada hegemoni satu mazhab pemikiran atas pihak-pihak lain di luar mereka. Hubungan antar mereka adalah sejumlah relasi harmonis yang dibangun berlandaskan asas tenggang rasa dan tepo seliro. Contoh terbaik dalam hal ini adalah apa yang diperankan oleh Malik ibnu Anas ketika menolak permintaan khalifah Abu Ja'far untuk mempromosikan dan memformalisasikan mazhab fiqh Maliki. Di mata Malik, masing-masing masyarakat sudah mempunyai pegangan dalam memutuskan apa yang dianggap baik oleh mereka, justeru dengan melakukan hegemoni satu nalar pemikiran tertentu dapat menyebabkan gangguan pada stabilitas sosial masyarakat ('Asyur, 2006).

Memang, mungkin akan terlihat naif jika suatu bangunan teori, ompong tak berdaya bila dihadapkan dengan realitas yang ada di hadapan kita. Urgensi dari 
aplikasi sebuah teori, mutlak diperlukan guna membuktikan keabsahan sebuah teori. Adalah omong kosong, bila sebuah teori nihil data dan miskin aplikasi. Oleh karena itu di bagian akhir bukunya, Thahir ibnu'Asyur berusaha menjadikannya sebagai bentuk kongkret aplikasi dari kaidah-kaidah maqasid universal (maqasid alsyari'ah al-ammah). Bentuk aplikatif ini tertuang pada berbagai aspek, meliputi liturgi keagamaan (ibadah), pola interaksi sosial (muamalat), hukum pidana dan perdata.

Pada bagian tersebut, ia ingin membuktikan bahwa maqasid al-syari'ah bukan hanya konsep utopis tanpa realisasi. Contoh-contoh aplikasi yang dikemukakan oleh Thahir ibnu 'Asyur tidak saja mampu membantu mempertemukan dua aliran yang saling berseberangan. Fiqh dan realitas tidak saja nyata ke dalam satu muara sama, tetapi juga sebentuk tawaran konsep baru dalam memandang syariat, yang bermuara pada maslahat.

\section{Kesimpulan}

Ibnu Qayyim berkata: “Syariah dibangun dengan berpondasikan kemaslahatan hamba di dunia dan akhirat, karenanya ia adil sepenuhnya, rahmat seluruhnya, dan penuh akan ujaran hikmah mulia di dalamnya”. Sejak awal mula turunnya wahyu Tuhan di muka bumi, manusia, sebagai pengemban amanat risalah ilahiyyah telah melalui berbagai macam perubahan, baik perubahan budaya maupun perubahan gaya hidup dan cara pandang terhadap dunia. Nilai-nilai yang baik pada suatu masa, dimungkinkan tunduk pada gilasan roda sejarah, dan berubah menjadi onggokan cerita kuno yang tak bernilai apapun.

Ada respon besar terhadap usaha keras Thahir ibnu 'Asyur dalam mengembangkan ilmu maqasid al-syariah. Pendekatan yang dilakukannya terhadap universalitas syari'at merupakan sesuatu sangat diperlukan, lebih-lebih di era globalisasi seperti sekarang ini yang mengandaikan perubahan serba cepat dan tidak diperhitungkan sebelumnya. Berpegangan pada rumusan fiqh klasik, akan menjauhkan diri kita dengan realitas yang ada dihadapan kita. Penyebebnya adalah background sosio historis kita yang sama sekali berbeda dengan masa dimana para sarjana klasik merumuskan ide-idenya. Apabila hal ini dipaksakan, maka bentuk hukum yang dihasilkan akan terasa aneh, rigid, dan ahistoris. Seperti yang diwacanakan oleh Thahir ibnu 'Asyur bahwa sebab utama kemunduran fiqh adalah abainya para sarjana akan studi maqasid yang akan mengantarkan kita kepada 
pengkebiran nilai-nilai syariat itu sendiri. Sementara 'Allal al-Fasi menegaskan bahwa syarat utama keberhasilan mendialogkan fiqh dengan realitas kontemporer sekarang ini adalah banyak tidaknya sambutan para cendekiawan terhadap studi maqasid.

Dalam konteks di atas, maqasid al-syari'ah menemukan momentumnya. Dengan karakternya yang elastis, lintas ruang dan waktu diharapkan ia mampu berdialektika dengan problematika yang terus bermunculan. Dengan ciri khasnya yang syumul, diandaikan mampu merangkul setiap peradaban yang berjalan. Ia, sebagai salah satu diskursus keilmuan yang merupakan anak kandung peradaban Islam dan jauh dari pengaruh asing, diharapkan dapat berperan sebagai pendobrak kelesuan peradaban Islam yang lama mati suri. Ia, sebagaimana ditegaskan alQardhawi (Al-Qardhawi, 2008), berperan sebagai bapak dari seluruh disiplin keilmuan Islam yang selayaknya memberikan kontribusi besar demi membesarkan anak-anaknya. Karenanya, kita layak menitipkan banyak harapan kemajuan Islam dari studi maqasid ini. Tentunya dengan semangat usaha bersama diantara seluruh komponen umat Islam. Semoga bermanfaat. Wallahu a'lam bi al-shawab.

\section{DAFTAR PUSTAKA}

'Asyur, M. T. (1984). Alaisa al-Subh bi Qarib. Tunisia: Dar al-Tunisiah li alNasyr.

'Asyur, M. T. (2006). Ushul al-Nidzam al-Ijtima'i (2nd ed.). Kairo: Dar al-Salam.

'Âsyûr, M. T. I. (2001). Maqâsid al-Syarîtah al-Islamîyah (2nd ed.). Yordania: Dâr al-Nafâe is.

Abdullah, M. A. (1995). Falsafah Kalam di Era Postmodernisme. Yogyakarta: Pustaka Pelajar.

Al-Fasi, 'Allal. (1993). Maqasid al-Syari'ah al-Islamiyah wa Makarimiha. Beirut: Dar al-Gharb al-Islami.

Al-Hasanî, I. (1995). Nazarîyat al-Maqâsid 'inda Muhammad Tâhir ibnu 'Âshûr. Virginia: al-Ma'had al-'̂́lam li al-Fikr al-Islâmî.

Al-Khadimy, N. (1998). Al-Ijtihad al-maqasidy. Qatar: Wizarah al-auqaf wa alsyuun al-Islamiah.

Al-Misawî, M. T. (2001). Kata Pengantar" dalam Maqâsid al-Syarîtah alIslâmîyah (2nd ed.). Yordania: Dầr al-Nafâis. 
Al-Muqrî, A. b. M. b. 'Alî al-F. (1987). Al-Misbâh al-Munîr fî Gharîb al-Syarh alKabîr li al-Râfi î. Beirut: Maktabah Lubnan.

Al-Qardhawi, Y. (2008). Dirasah fi Fiqh Maqasid al-Syariah (3rd ed.). Kairo: Dar al-Syuruq.

Ash-Shiddieqiy, N. (1998). Jeram-jeram Peradaban Muslim. Yogyakarta: Pustaka Pelajar.

Khalid, I. (1995). Muhamad Tahir ibnu'Asyur. Damaskus: Dar al-Qalam.

Mawardi, A. I. (2012). Fiqh Minoritas Fiqh Al Aqalliyyat dan Evolusi Maqasid al Syari'ah Dari Konsep Ke Pendekatan. Yogyakarta: LKIS.

Raisuni, A. (1995). Nadzariat al-Maqasid 'inda Imam al-Syathibi. Jeddah: Dar alIlmiah li al-Kitab al-Islami.

Raisuni, A. (2003). Al-Bahts fi Maqasid Asy-Syari'ah; Nassy'atuh wa Tathawwuruh wa Mustabaluh. London: Muassasah Al-Furqan li al-Turats.

Santhleir, B. (2008). Al-Siyasah li Aristoteles, Diterjemahkan dalam bahasa Arab oleh Ahmad Luthfi Sayyid. Kairo: Haiah al-Misriah al-'Ammah. 